\title{
Developing Writing Materials Based on CTL Approach for Indonesian EFL Learners
}

\author{
Sri Wahyuni \\ wahyu_uni78@yahoo.com \\ STAIN Kediri \\ Jl. Sunan Ampel No. 7, Ngronggo, Kediri, Jawa Timur, Indonesia
}

Received: February 6, 2017; Accepted: March 4, 2017; Published: March 7, 2017

\begin{abstract}
This study aims at developing writing materials based on Contextual Teaching and Learning (CTL) approach for Indonesian EFL learners. It adapted R and D development model proposed by Borg and Gall consisting of seven steps: research and information collection, developing a preliminary product, expert validation, product revision, field-testing try-out, revision, and final product. On the basis of preliminary research and information collections result, the preliminary product was produced by considering the seven principles of CTL approach. From the expert validation, it shows that the developed material was on good criteria and eligible to be used as the handbook or instructional materials for Writing II. However, the expert suggested revising some points on making clearer instruction, reflecting the activities to the topic/subtopic, revising the typing errors, and arranging the spacing among the sections. After revising, it is tried out to the students. The result of the try-out shows that the product was categorized on good criteria. Based on the students' comments, the content of the product had been already complete and interesting. The provision of more than one model texts made students understand the topic more easily. Next, the various activities provided (individual, peer, and group) made the materials more interesting.
\end{abstract}

Keywords: writing skill, instructional materials, contextual teaching and learning approach

How to cite this paper: Wahyuni, S. (2017). Developing Writing Materials Based on CTL Approach for Indonesian EFL Learners. Journal on English as a Foreign Language, 7(1), 97-118.

Journal on English as a Foreign Language, 7(1), 97-118

Copyright @ 2017 by JEFL, p-ISSN 2088-1657; e-ISSN 2502-6615 
Writing is one of English language skills that must be mastered by college students. It plays an important role in their personal and professional lives. Writing has become one of the essential components in English for General Purposes (EGP) and English for Academic Purposes (EAP) curricula. Its multivarious pedagogical purposes range from reinforcement, training, and imitation (generally in the early stages of instruction) to communication, fluency, and learning (at intermediate and more advanced level). Based on the literacy-based approach, the language learning should focus more on literacy skills, reading, and writing. The emphasis on the reading and writing skills is intended to support the learning process.

Writing has been widely believed that among the four language skills, it is the most difficult skill. It involves several components which have to be considered while the learners are writing, for example, contents, rhetoric, vocabularies, grammatical structure and writing mechanics such as punctuation and capitalization. Writing is different from speaking. In speaking, someone can acquire naturally as $\mathrm{s}$ he grows up, but the writing needs to be learned first since s/he does not acquire writing naturally. So, it is a need to find an effective approach to solve the problem

Writing is one of the compulsory courses at English Education Study Program at STAIN Kediri that must be taken by the students. The teaching of writing is distributed into courses namely Writing I which is offered in the second semester, Writing II which is offered in the third semester, Writing III which is offered in the fourth semester, and Scientific Writing which is offered in the fifth semester. Writing I focuses on sentence construction; Writing II discusses paragraph development; Writing III emphasizes on essay writing, and Scientific Writing focuses on articles writing. Each course has two credits.

Based on the researcher's observation and informal interview with some students of Writing II class in the third semester of English Education Study Program, there are some problems related to students' lack of writing skill and motivation in writing. This condition is caused by the unavailability of a developed teaching material for Writing II. The lecturer just takes the materials from several writing textbooks and internet resources without organizing it well before distributed to the students.

Moreover, the existing textbooks are written in abroad, so the background or the social context of the topics is based on the countries which are different with the students' context. This condition decreases the students' motivation in joining the class. They face some difficulties in comprehending the language used in the materials, lack of knowledge in the text structure, uninteresting layout of the materials, no feedback on students' work, and monotonous writing activities. 
The teaching and learning should not only focus on classroom activities that have nothing to do with outside the classroom, but also relate it to the students' daily life. A language should be taught based on an approach which requires the students to use the language in real context. The limited number of instructional material in the form of a good textbook and suitable with the students' daily life also influences the teaching and learning process. Good textbooks give great support to the success of teaching and learning process. A textbook including all materials, tools, and ways structured systematically can help students to study by themselves or with teacher's guide to reaching the objective of the teaching and learning activities.

Textbooks on English writing are available in the market. However, we cannot directly decide which one(s) to choose as many factors must be taken when evaluating materials for use with speakers of other languages. The factors are the objectives, the learners' ability, the approach used, and the authenticity of the language (Griffith, 1995, p. 50-51). In addition, most of the writing textbooks are written in abroad, so the backgrounds or the social context of the topics are based on the countries which are different with the students' context. Moreover, according to Nunan (1991), commercial materials are sometimes incapable of catering for the diversity of needs existing in the most language classroom and students' daily life. They only fulfill an important teacher education function and remove much of the burden and time in creating materials from scratch. For this reason, he recommends that teachers design their own instructional materials to ensure that the materials are consistent with the needs and interests of the learners and to ensure that they are in harmony with the institutional objectives (Nunan, 1991).

The appropriate approach used in this study is Contextual Teaching and Learning approach since this approach is based on the premise that students learn when they see meaning in the academic material; when they connect new information with prior knowledge and apply their knowledge and their own experience. Contextual Teaching and Learning enable students to reinforce, enlarge and apply their knowledge and language skills in various situations, whether it is in the school or outside of the school. Johnson (2002, p. 25) defines Contextual Teaching and Learning (CTL) as an educational process that aims to help students see meaning in the academic material. The students are studying by connecting academic subject with the context of their daily lives; this is, in the context of their personal, social, and cultural circumstances. Then to achieve this aim, the system encompasses the following eight components: making a meaningful connection, doing significant work, self-regulated learning, collaborating, and critical thinking, nurturing the individual, reaching high standards and using authentic assessment. 
In the CTL approach, there are seven principles: constructivism, questioning, inquiry, and modeling learning community, authentic assessment, and reflection (Suyanto, 2009, p. 11-12). First, constructivism is a learning theory that claims that people construct or build their own sense and meaning from new experiences based on their prior knowledge and belief. Second, questioning is a strategy that is used by teachers to guide students' thinking, to assess students' understanding. Students learn how to pose questions about phenomena, how to formulate a question that can be tested and learn how to ask each other about evidence, interpretation, and explanation. Third, an inquiry is a process moving from observation to understanding. Fourth, learning community is a concept based upon an idea that learning occurred by working together is greater than by individual. Fifth, modeling is a process of providing an example of how you want others to be, to think, to act and to learn. Sixth, authentic assessment is a variety strategy used to evaluate students' knowledge and skills. Finally, reflection is a way of thinking about what we have learned and helps us figure out our own personal meanings. In line with this approach, the material should be redesign in such a way that the teachers can provide students with the activities that enable them to connect Writing course to their prior knowledge and the situation that require them to use English. In this case, the material is presented on some topics from the context of the students' world.

A good textbook- one that meets students' need is at the right level and has interesting material. However, no textbook was written for an actual group of students, and so it will need to be adapted in some ways. One consideration in adapting a textbook is the social context where the teaching and learning process takes place. Jaya's (2007) study on developing a pragmatic workbook for English department students of Muhammadiyah University of Bengkulu found that the workbook was suitable and applicable to the students who learned pragmatics for the first time because it contained the basic concept of pragmatics and simple exercises. Ningrum's (2014) study found that the teacher's handbook for essay writing has a beneficial favor that is able to be used in self-study; however, only a few handbooks is relevant to the students' real-life.

Developing and presenting material which takes the context of the students will, at least, give two advantages. Firstly, showing interest in students' home cultures and ethnic background builds trust in the classroom. Building trust with students of diverse backgrounds is a culturally responsive strategy that is often overlooked. Secondly, presenting context based writing material will develop students' schema (prior knowledge) about the topic being learned. Moreover, Students are in a strategic position to learn with topic 
whenever they use prior knowledge to construct meaning for new material that they are studying. Therefore, it is important to supply schools or university with a textbook that present materials by taking the concept of the students.

Research on developing materials at the university level has been conducted (Jaya, 2007; Ary, 2014; Umam, 2015). As stated previously, Jaya (2007) conducted a research and development on a pragmatic workbook for English department students of Muhammadiyah University of Bengkulu. He found that the workbook was suitable and applicable to the students. In line with Jaya (2007), Ary's (2014) study conducted at English department of STAIN Kediri also found that teacher's handbook for essay writing has a beneficial favor that is able to be used in self-study. Furthermore, Umam's (2015) study conducted at English department of STAIN Kediri also found that the instructional materials developed were appropriate for students in learning English morphology. The provision of simple language use and exercises in the materials makes the students easier in understanding the materials.

In accordance with the elaborate background above, there is a need to conduct a deeper study focusing on the developing writing material based on contextual teaching and learning approach for the English students of STAIN Kediri. Therefore, the purpose of this study is to develop writing materials for English students of STAIN Kediri based on contextual teaching and learning approach. Through this approach, it is expected that the materials can be developed in order to make students connect their academic knowledge with their daily life.

\section{METHOD}

This chapter section discusses the description of the research method employed in the present study. It covers the research design, model of development, procedure of the development, research instrument, research treatment procedure, data collection, and data analysis.

\section{Research Design}

The purpose of this study is to develop instructional materials for Writing II course at English Education study program of STAIN Kediri. Hence, the appropriate research design used in this study is research and development ( $R \& D$ ) since it is designed to develop materials for use in education. The main purpose of research and development ( $\& D$ ) is not to formulate or test a theory like in the basic research, but it is to develop effective products for use in school.

Borg and Gall (1983, p. 772) state that the objective of R \& D is to produce finished products like textbooks, audio-visual games, training manuals, 
equipment, etc., that are usable in an educational program. It is a process used to develop and validate the educational product. They propose ten steps of $\mathrm{R} \&$ D cycle; those are (1) research and information collection, (2) planning, (3) preliminary form of product, (4) preliminary field-testing, (5) main product revision, (6) main field-testing, (7) operational product revision, (8) operational field-testing, (9) final product revision, and (10) dissemination and implementation (Borg \& Gall, 1983, p. 775).

\section{Model of the Development}

In line with the purpose of the study, the research and development $(\mathrm{R} \&$ D) design proposed by Borg and Gall (1983, p. 775) is adapted. The adaptation is done by modifying the steps of the process based on the problem found, the purpose of the research, and the time limitation in conducting this research. The adapted model used in this study is (1) research and information collection (2) developing a preliminary product, (3) expert validation, (4) product revision, (5) field-testing/ry-out, (6) revision, (7) final product.

\section{Procedure of the Development}

It is stated previously that this study adapted the $R$ and $D$ design proposed by Borg and Gall (1983, p. 775) by modifying the steps. The adapted model consists of seven steps as follows.

\section{Research and Information Collection}

The research and information collection stage was conducted by the researcher during the teaching and learning process of Writing II for five academic years. This research and information collecting include a review of the literature, classroom observations, and preparation of report writing. Then reference study was also conducted. In this stage, the theories that can be used as the basis for development are studied. The theories such as the concept of academic writing, the concept of context (Contextual Teaching and Learning), the concept of material development, and the strategies for developing writing skill.

\section{Developing Preliminary Product}

The next stage was developing a preliminary product of writing. In this stage, the theories that have been studied in the previous stage are used as the basis to develop the material. The development itself comprised some stages adapted from those suggested by Borg and Gall (1983) and Nunan (1991). The selected instructional materials were developed in some steps. The step was determining the general and specific instructional objectives, determining the rhetorical and language focus, selecting model texts, and creating tasks and 
activities on writing which consisted of tasks as opening activities, main activities, and closing activities.

\section{Expert Validation}

The next step in the development process is a validation of the material. In this stage, the materials that have been made will be evaluated by a person who is considered an expert in the material development as well as in the Contextual Teaching and Learning approach. The evaluation is made to give evidence whether the developed material have met the criteria of good materials or not.

\section{Revision}

The next stage is a revision. In this study, there are two kinds of revision. The first revision is done when the data collected during the expert validation indicated that the developed material does not meet the criteria set or the purpose of this study. The second revision is done when the data collected from a tryout of the revised material still indicates difficulties or problems experienced by the students in their effort to achieve the performance objectives stated in each unit of the material.

\section{Try-Out of the Material}

After the material has revised, the next stage is doing try-out of the material. It is called empirical validation. The purpose is to know whether the revised material worked well for the students, whether it really help the students in attaining their mastery of writing skill as stated in the objective of the writing course. The try-out is mainly intended to gather information for the applicability of the material, in term of the level of difficulty, usefulness, effectiveness and attractiveness of the material, for the students.

\section{Revision}

As stated previously, the second revision was conducted after fieldtesting or try-out was conducted. It was conducted when the data collected from a tryout of the revised materials still indicates difficulties or problems experienced by the students in their effort to achieve the performance objectives stated in each unit of the material.

\section{Final Product}

The last stage of developing the materials was writing the final product. After conducting the second revision, the final product would be published. The final product must be an educational product that is ready to support teaching and learning process. In this research, the researcher planned to produce instructional materials for Writing II course based on contextual teaching and learning approach for English students of STAIN Kediri. 


\section{Types of Data}

The data collected in this study was classified into three: First, the data collected from the research and information collection. It was used as the basis to develop the material. Second, the data were given by the expert in the validation process. It was used to determine whether the material had been developed in accordance with the theories underlying it. Third, the data gathered during the tryout. The data was used to determine the applicability of the material for the second-year students of English department of STAIN Kediri.

\section{Research Instruments}

There are three types of data used in this study collected from different sources and different instruments used. To collect the data from the research and information stage, preliminary observation, field notes, and unstructured interview were used as the instruments. The preliminary observation was conducted during the teaching and learning process of Writing II for five academic years. Reference study was also conducted to collect the data.

To get the data from expert's validation, a questionnaire was employed as the instrument of this study. The questionnaire for content and material development expert was developed by Brown (2001, p. 432). The reason for choosing the questionnaire is because it is in line with the need of the present study. The questionnaire consists of ten aspects including the objectives, topics, organization, content, coverage, language, instruction, examples, exercises, and other aspects. Comment and suggestions column is provided for the expert to give a review on the material freely. The complete questionnaire can be seen Appendix 1.

To get the data during the field try-out, a questionnaire adapted from Polly (2009) was employed as the instrument in the present study. The questionnaire consists of some points about the suitability of the materials with the objective, the format, the relevance to the students' needs, the content, the instruction, the role of the teacher, and the length of delivery in each meeting. Comment and suggestion column is also provided in the questionnaire. The results of this questionnaire are recorded and used to improve the product.

\section{Data Collection}

The data collected in this study was very important and useful to determine the validity and applicability of the developed material. To collect the first data, the researcher conducted an observation during the teaching and learning process of Writing II for five academic years. The second data is gathered through consultations with an expert in academic writing and 
Contextual Teaching and Learning approach as well as in the material development. For the third data, which is the data of trying out, is collected in two different ways: through observation and a questionnaire.

\section{Data Analysis}

The data gathered from the preliminary observation in the research and information collection were analyzed in such a way to describe the actual students' needs in the target situation This description is used as a guidance in determining whether the material has been appropriately developing. Since there are still deficiencies in the material, the data is used as the guidance to make a revision.

Furthermore, the data collected from the expert validation and students' responses during the tryout were calculated in the form of a percentage. Both data were classified and analyzed as a basis for further revision of the product. To calculate the items given in the questionnaires, statistic descriptive analysis was employed in this study through the following formula (Sugiyono, 2008).

Percentage $=\sum$ (response $\mathrm{x}$ weighting on each response) $\times 100 \%$

$\mathrm{N} x$ weighting the highest response

Note:

$\sum \quad$ : total number

$\mathrm{N} \quad$ : the total number of the whole questionnaire items

Percentage : F N

$\mathrm{F} \quad$ : the total number of the whole subjects

$\mathrm{N} \quad$ : the number of the subjects

To decide the quality of the product, an achievement level conversion with scale 5 was employed in the present study. The conversion was described in Table 1.

Table 1. Validity Level Conversion

\begin{tabular}{ccc}
\hline Percentage & Qualification & Discussion \\
\hline $90 \%-100 \%$ & Very Good & No need revision \\
\hline $75 \%-89 \%$ & Good & Need revision \\
\hline $65 \%-74 \%$ & Enough & Need revision \\
\hline $55 \%-64 \%$ & Poor & Need revision \\
\hline $0 \%-54 \%$ & Very poor & Need revision \\
\hline
\end{tabular}

Journal on English as a Foreign Language, 7(1), 97-118

Copyright (C) 2017 by JEFL, p-ISSN 2088-1657; e-ISSN 2502-6615 
According to Leatamia (2010), if the score is above $71 \%$, it means that the development materials are eligible to be used by the users.

\section{FINDINGS}

This section presents the result of the preliminary research and information collecting, the result of the expert's validation, and the result of tryout. After the draft had developed, it was given to the expert to be validated, revised, and then tried out to the students. Two forms of questionnaires were given to the expert and the students to evaluate and give suggestions to the materials.

\section{The Result of Preliminary Research and Information Collecting}

As stated previously, preliminary research and information collecting were conducted during the teaching and learning process of Writing II. The result of preliminary research and information collection shows that the role of English writing skill is really important for their academic purposes (EAP) and general purposes (EGP). However, the books available in the library are not suitable for their purpose and the objective of Writing II courses.

Furthermore, the lecturer so far just takes the materials from some writing textbooks and internet resources without organized it well. In addition, the textbooks are written in abroad so that the background or the social context of the topics is based on the countries which are different with the students' context. This condition decreases the students' motivation in joining the class. They face some difficulties in comprehending the language used in the materials, lack of knowledge in the text structure, uninteresting lay out of the materials, no feedback on students' work, and monotonous writing activities.

Therefore, the researcher designed a preliminary product which consisted of three parts. The first part consists of the cover, preface, and table of content. The second part is the main part of the product which consists of some units. Each unit covers cover one kind of paragraph. It contains the theory, model paragraph and exercises to improve students' knowledge of writing and writing skills. Then it is followed by process writing for students to practice writing based on their knowledge. This process consists of some steps, namely prewriting (brainstorming and outlining), drafting, revising, editing, and final drafting. It also provides self-editing checklist and peer editing checklist to reinforce students' knowledge. This part is constructed by considering the seven principles of contextual teaching and learning approach (constructivism, questioning, inquiry, modeling, learning community, authentic assessment, and reflection). The last part consists of bibliography. After the preliminary product was constructed, the next step was validating it to the expert. 


\section{The Result of Expert's Validation}

After writing the draft of developed materials, it was given to the experienced writing lecturer to be validated. A questionnaire was given to the expert as the instrument to collect the data. It consisted of ten aspects with thirty-five statements. The highest score of the each statement was five, and the lowest score was one. Five represented strongly disagree; four represented agree; three represented moderate; two represented disagree, and one represented strongly disagree. The complete result of the questionnaire can be seen in Appendix 1.

The expert's scores on the developed materials were mostly 4 (agree) and 5 (strongly agree). In term of the objectives, the developed materials are clear and complete enough. The objectives reflect the topics/subtopics and ordered appropriately. Next, the topics are relevant to writing the subject, suitable to real life and have various kinds. Furthermore, the materials are systematically organized.

The content for each meeting is quite sufficient and suitable with the objectives. The explanation is quite sufficient and accurate. Furthermore, the developed material contains various and interesting activities to help the students develop writing skill. It covers both knowledge and skill. It represents the aspect of writing: language, content, rhetoric.

The language used in the developed material is understandable and clear. It is suitable to the level of the students. Language focus concerns certain relevant grammatical patterns. The instructions are quite clear, focused, simple, and specific. They reflect the gradation of the exercises. Then the examples are clear and appropriate. The concepts can easily be understood through the examples used. Furthermore, the existing of modeling texts are good examples for the purpose of understanding the concepts. The exercises in the developed materials promote students' knowledge of the topics and their writing skill. They quite are clear and appropriate. The exercises enable the students to work individually and collaboratively as well.

Furthermore, the cover of the book is interesting and suitable with the content. The size is suitable for the students, and the design is quite interesting. The choice of the letter is suitable for the students. The use of space, title, and subheadings are quite consistent. The use of table and figure in the book is quite suitable with the topics. Then the presentation or the arrangement of the materials is quite interesting. The use of page is helpful for students or readers.

The total score of the expert's validation is 156. The data collected then calculated using a formula as follows to find out the validity level. 
Percentage $=\sum$ (response $\times$ weighting on each response) $\times 100 \%$

$$
\begin{aligned}
& =\underline{156} \times \mathbf{3 5 \times 5} \times 100 \% \\
& =\underline{156} \\
& =89 \%
\end{aligned}
$$

From the calculation, it can be concluded that the developed materials were categorized on good criteria. Based on the expert's comments, the developed materials were generally good and eligible to be used as the handbook or instructional materials for Writing II. Generally, the content and the language used were considered good. The provision of various modeling texts helped the students to understand the rhetorical focus of the topic. Moreover, the provision of editor's checklist would make the students get more feedback on their writing.

However, some points needed to be revised. The expert suggested to provide self-editing checklist so that the students could check their own writing to improve their autonomous learning. Next, the instructions needed to be revised to be clearer and simple. Then the activities/exercises should reflect the topic/subtopic. Furthermore, there were some typing errors, and the spacing among the sections should be rearranged.

Based on the result of the expert's validation, the drafts of the developed materials were revised. Self-editing checklist for each topic was provided to develop students' self-learning or autonomous learning from their own writing. The instructions of each topic were revised to be clearer and simpler. Next, the activities/exercises were revised to reflect the topic/subtopic. Some typing errors and the spacing among the sections in the develop materials were revised and rearranged. Furthermore, the researcher asked a person to proofread the developed material.

\section{The Result of Try-Out}

After the draft of the developed materials was revised based on the expert's validation, it was then tried out to students in the class of Writing II. It was conducted in five sessions in September to October 2016. The materials of the try-out were limited to Unit 1 (introduction to paragraph), Unit 2 (simple paragraph outlining), Unit 3 (Unity and coherence), Unit 4 (writing process), and Unit 5 (putting it all together). The try out was conducted to find out more about the appropriateness and the usability of the developed materials. It was conducted to get more information on the process of teaching and learning using the developed materials. 
In conducting the try out, the researcher acted as the lecturer. The implementation of try out ran well. The students seemed motivated in following the try out. Furthermore, the atmosphere was quite conducive since the students were excited in following the try out. The materials were presented without encountering any difficulty. In the fifth meeting, the students were asked to answer a questionnaire. The highest score of the statement was five, and the lowest was one. The complete students' answer scores on the questionnaire are presented Appendix 2.

The range of the total students' scores is from 73 to 87 . The total number of scores for all items is 881 . Then based on the data collected, the value was calculated using the following formula:

Percentage $=$ Total number of score in all items $\times 100 \%$

Total number of the highest score in all items $\mathrm{x}$ total students $=\underline{881} \times 100 \%$

1100

$=80.1 \%$

The result of the conversion to validity level shows that the developing material was categorized on good level criteria. Based on the students' comments, the content of the developed materials had been already complete and interesting which consisted of objectives, concepts/rhetorical and language focus, model texts, exercises, self and peer editing. The provision of more than one model text made students understand the topic more easily. Next, the various activities provided (individual, peer, and group) made the materials more interesting.

Then the content of the developed materials was understandable and helpful for students to develop their writing skills and knowledge on writing. It also motivates students to study. Furthermore, the developed materials also helped the students to develop their other English skills (listening, reading, and speaking) and English components such as vocabulary. However, the students suggested revising the developed materials especially on mistyping. They also suggested giving more pictures to make the developed materials more interesting.

Based on the result of the try out, the final product was then produced. Some mistyping words in the developed materials were revised. Furthermore, more pictures were also provided to make the materials more easily to understand. The sample of the final product can be seen in Appendix 3. 


\section{DISCUSSION}

As stated previously that the purpose of this study is to develop instructional Writing materials for teaching Writing II for the students at the third semester of English Education Study Program at STAIN Kediri. The developed materials are based on Contextual Teaching and Learning approach. The principles of contextual teaching and learning approaches such as constructivism, inquiry, questioning, modeling, learning community, authentic assessment, and reflection are implemented in the developed materials. The purpose of the implementation is to help teachers connect the subjects to the real situation (Sears, 2001).

The results of the study show that the instructional material which is developed by using Borg and Gall's (1983) model of development obtain a positive response from the students because the materials can motivate students to learn in writing class. The atmosphere of the teaching and learning process was quite conducive since the students were excited in following the class. The materials were presented without encountering any difficulty. The materials help the students develop their writing skill and knowledge in writing, and connect it to their daily life. The reasons are because the materials have been developed based on the students' need, theoretically and empirically validated to the expert, and accommodated the comments and suggestion from the expert and the students as the users.

The result of the study proves that contextual teaching and learning approach is beneficial to be implemented in developing instructional materials for writing skill. The principle of constructivism is implemented in the instructional activities that build up knowledge that students already know. In Writing I course, the students had learned about sentence building; hence, the activities in the developed materials for Writing II course are the implementation of sentences writing in a paragraph forms. Constructivism is building knowledge by own self from new experiences based on the previous experience (Suyanto, 2009, p. 11).

Furthermore, the topics were selected based on the students' need and the objectives of the Writing II course. The instructional materials are designed to develop students' writing skill and knowledge on writing through questioning, inquiry, modeling, learning community, and reflection. Each topic of the developed materials starts with the rhetorical focus of the topic that also asks the students to find more information about the topic. This leads the students to apply the inquiry phase and leads the question and answer activities between the lecture and students or among the students.

Modeling text provided in the instructional materials gives an opportunity for the students to understand more easily about the topic. It also 
gives students prior knowledge of the topic (Nurdin, 2009). Through modeling, the teacher can demonstrate how the teacher wants students to learn, and to do what the teacher wants to do.

The provision of pair and group activities of writing in the developed materials reflects the implementation of a learning community. Group brainstorming phase in the writing process makes the students have more idea before starting to write their draft. Furthermore, learning in a group helps the students to interact with other students. Through interaction, they can share ideas, and learn to raise mutual understanding (Nurdin, 2009).

Authentic assessment is implemented through the collection of students' writing in the whole semester. The final students score is not only taken from the students' test results, but also from the students' result of writing during the teaching and learning process. This developed material asks the students to write on every topic; hence, the lecturer will have the collection of students' writing. The authentic assessment gives students the change to exhibit the full range of their abilities while showing what they have learned. (Johnson, 2002, p. 165).

Reflection before the end of each meeting is one of the important parts in these developed materials. It is the evaluation towards the effectiveness of the learning and teaching activities to determine which parts of the topic to be improved, and to identify the weakness of the instructional process (Umam, 2015). The provision of self-editing guidance and peer-editing guidance also can be the reflection of the students' writing. They can edit and revise their writing after getting a correction.

\section{CONCLUSION}

The final product of this study is an instructional material (handbook) for teaching Writing II course which focuses on paragraph writing. The product had been developed based on contextual teaching and learning approach which consists of seven principles (constructivism, inquiry, questioning, modeling, learning community, authentic assessment, and reflection).

The developed material comprises three parts. The first part consists of the cover, preface, and table of content. The second part is the main part of the product which consists of some units. Each unit covers one kind of paragraph. It contains the theory (rhetorical focus), model paragraph and exercises to improve students' writing skills. Then it is followed by process writing for students to practice writing based on their knowledge. This process consists of some steps, namely prewriting (brainstorming and outlining), drafting, revising, editing, and final drafting. It also provides peer editing checklist to reinforce students' knowledge. The last part consists of bibliography. The 
expert validation and trying out the developed materials was also conducted to get the appropriate product for teaching paragraph writing.

The developed materials obtain a positive response from the students. The materials are understandable and helpful for students to develop their writing skills and knowledge on writing. The materials can motivate students to learn in writing class. The result of this study proves that contextual teaching and learning approach is beneficial to be implemented in developing instructional materials for writing skill.

This developed material, however, is not the end of this long process. The teacher/lecturer are suggested to review it first, or if it is needed, to revise and to adapt depending on their instructional setting. For the further researcher, conducting a research on investigating the effectiveness of the use of this developed material is much needed. It can be by comparing between pretest (before implementing the materials) and post-test (after implementing the material), or by comparing two groups which use the developed material and without use the developed material.

\section{REFERENCES}

Borg, W. R., \& Gall, M. D. (1983). Educational research: an introduction. New York and London: Longman.

Brown, H. D. (2001). Teaching by principles: An interactive approach to language pedagogy (2nd edition). New York: Pearson Education.

Griffith, C. (1995). Evaluating materials for teaching English to adult speakers of other languages. Forum 33(3), 50-51.

Jaya, S. (2007). Developing a pragmatic workbook for English department students of muhammadiyah university of Bengkulu. Unpublished Thesis. Malang: State University of Malang.

Johnson, E. B. (2002). Contextual teaching and learning. Thousand Oaks: Corwin Press.

Leatamia, M. (2008). Pengembangan paket pembelajaran mata kuliah bahasa Inggris teknik I dengan pendekatan fungsional kontekstualisme materi ESP untuk mahasiswa teknik mesin pada politeknik negeri Ambon. Unpublished Thesis. Malang: State University of Malang.

Ningrum, A. S. B. (2014). Developing a writing workbook for Indonesian college students of English. Jurnal Bahasa dan Seni, 42(2), 137-142.

Nunan, D. (1991). Teaching methodology: A text book for teachers. Hertfordshire: Prentice Hall International.

Nurdin. (2009). Teaching recount texts using the contextual teaching and learning approach. In Cahyono, B. Y. 2009. Techniques in Teaching EFL Writing. Malang: State University of Malang Press. 
Polly, Y. E. (2009). Developing writing materials for the students of the English language study program of STKIP Santa Paulus Ruteng. Unpublished Thesis. Malang: State University of Malang.

Sears, S. (2001). Contextual teaching and learning: A primer for effective instruction. Bloomington: Phi delta Kappa Educational Foundation.

Sugiyono. (2008). Metode penelitian kuantitatif, kualitatif dan $R \mathcal{E} D$. Bandung: Alfabeta.

Suyanto, K.K.E. (2009). Model-model pembelajaran. Malang: Universitas Negeri Malang Press.

Umam, C. (2015). Developing instructional materials of English morphology for English department college-learners. Journal on English as a Foreign Language (JEFL), 5(1), 1-8.

\section{Author's Brief CV}

Sri Wahyuni is an English lecturer at the English Study Program of STAIN Kediri. She got her undergraduate degree from STAIN Kediri in 2007. She earned her magister degree in 2010 and her doctoral degree in 2016 from the State University of Malang majoring in English Language Education. Her interests are academic writing, TEFL, and language assessment. She can be contacted via email wahyu_uni78@yahoo.com. 


\section{Appendix 1}

\section{THE RESULT OF EXPERT'S VALIDATION}

Criteria

1. The objectives are clear and complete. Score

2. The objectives reflect the topics/subtopic. 4

3. The objectives are ordered appropriately

4. The topics are relevant to writing a subject.

5. The topics are suitable for real life.

6. The topics are of various kinds.

7. The materials are systematically organized.

4

8. The topics and subtopics are ordered in line with the syllabus.

9. The content for each meeting is sufficient.

10. The content is suitable for the objectives.

5

11. The explanation is sufficient and accurate.

12. It contains various and interesting activities to help the students develop 5 writing skill.

13. The coverage represents the aspect of writing: language, content, rhetoric. 4

14. The materials cover both knowledge and skill.

15. The language is clear and understandable.

5

16. It is suitable to the level of the students.

5

17. Language focus concerns certain relevant grammatical patterns.

18. The instructions are clear and focused.

19. The instructions are simple and specific.

5

4

4

5

20. The instructions reflect the gradation of the exercises.

21. The examples are clear and appropriate.

5

22. The concepts can easily be understood through the examples used.

23. Modeling texts are good examples for the purpose of understanding the concepts.

24. The exercises promote students' knowledge of the topics and their writing 4 skill.

25. The exercises are clear and appropriate.

26. The exercises enable the students to work individually and collaboratively as well.

27. The exercises reflect the instructional objectives.

28. The cover of the book is interesting and suitable with the content.

4

29. The book size is suitable for the students.

30. The book design is interesting.

31. The choice of the letter is suitable for the students.

32. The use of space, title, and subheadings are consistent.

33. The use of table and figure in the book is suitable with the topics.

34. The presentation or the arrangement of the materials is interesting.

35. The use of page is helpful for students or readers. 


\section{Appendix 2}

\section{THE RESULT OF THE TRY-OUT}

\begin{tabular}{|c|c|c|c|c|}
\hline No & Criteria & Score & $\begin{array}{l}\text { Total } \\
\text { Score }\end{array}$ & $\begin{array}{l}\text { Percenta } \\
\text { ge }(\%)\end{array}$ \\
\hline 1. & Are the materials attractive to you? & $\begin{array}{l}4,4,4,4,4,4,4,4,4,4 \\
4,4,4,4,4,4,4,4,4,4\end{array}$ & 80 & 80 \\
\hline 2. & Do you enjoy using the materials? & $\begin{array}{l}3,4,3,3,4,5,4,4,5,3 \\
4,4,3,3,3,3,4,4,3,4\end{array}$ & 73 & 73 \\
\hline 3. & $\begin{array}{l}\text { Are the materials relevant to your } \\
\text { needs and interests? }\end{array}$ & $\begin{array}{l}4,4,4,3,4,4,4,4,4,4 \\
3,3,4,4,3,4,3,3,4,4 .\end{array}$ & 74 & 74 \\
\hline 4. & $\begin{array}{l}\text { Are the materials relevant to the real } \\
\text { life? }\end{array}$ & $\begin{array}{l}3,4,3,3,4,5,3,4,4,4 \\
4,3,4,3,5,3,4,4,4,4\end{array}$ & 75 & 75 \\
\hline 5. & $\begin{array}{l}\text { Do the materials help you to develop } \\
\text { your writing skill? }\end{array}$ & $\begin{array}{l}3,3,4,4,4,4,4,5,4,5 \\
4,3,5,4,4,5,5,5,4,4\end{array}$ & 83 & 83 \\
\hline 6. & $\begin{array}{l}\text { Is the language suitable to your } \\
\text { level? }\end{array}$ & $\begin{array}{l}3,4,4,3,5,4,4,5,4,4 \\
3,3,4,4,4,4,5,5,4,4\end{array}$ & 80 & 80 \\
\hline 7. & $\begin{array}{l}\text { Do the materials provide enough } \\
\text { concepts related to the topic? }\end{array}$ & $\begin{array}{l}4,4,5,4,4,4,4,5,4,5 \\
4,3,4,4,4,5,4,4,3,4\end{array}$ & 82 & 82 \\
\hline 8. & $\begin{array}{l}\text { Do the materials provide enough } \\
\text { examples? }\end{array}$ & $\begin{array}{l}5,4,4,5,5,4,4,5,4,4 \\
5,4,4,4,4,4,4,5,4,5\end{array}$ & 87 & 87 \\
\hline 9. & $\begin{array}{l}\text { Do the materials provide enough } \\
\text { exercises? }\end{array}$ & $\begin{array}{l}3,4,4,5,4,4,4,4,4,4 \\
5,3,4,3,4,4,4,5,5,4\end{array}$ & 81 & 81 \\
\hline 10. & Is the instruction clear? & $\begin{array}{l}4,5,3,4,5,5,4,5,5,5 \\
3,4,5,4,3,4,4,4,4,4\end{array}$ & 84 & 84 \\
\hline 11. & $\begin{array}{l}\text { Can you learn the materials without } \\
\text { teacher's guidance? }\end{array}$ & $\begin{array}{l}4,4,4,4,5,3,5,5,4,5 \\
5,4,4,4,3,4,4,3,4,4\end{array}$ & 82 & 82 \\
\hline
\end{tabular}


Appendix 3

\section{SAMPLE OF THE FINAL PRODUCT \\ UNIT II \\ PROCESS PARAGRAPH}

\section{PART I: $\quad$ RHETORICAL FOCUS}

$>$ Process Organization

PART II: $\quad$ LANGUAGE FOCUS

D Using time order words in process paragraph

$>$ Using imperative

$>$ Using modal of advice, necessity, and prohibition

PART III: WRITING FOCUS

$>$ Brainstorming ideas

$>$ Brainstorming vocabulary

$>$ Writing an outline

$>$ Writing the first draft

$>$ Revising and editing the first draft

$>$ Writing a final draft

\section{Exercise 1 Reading a model paragraph}

Read the model paragraph. What does the word "royalty" in the title refer to?

\section{Royalty in Your Garden}

Roses are royalty among flowers. Many people say that they are as difficult to maintain as kings and queens, but roses are actually quite easy to grow.

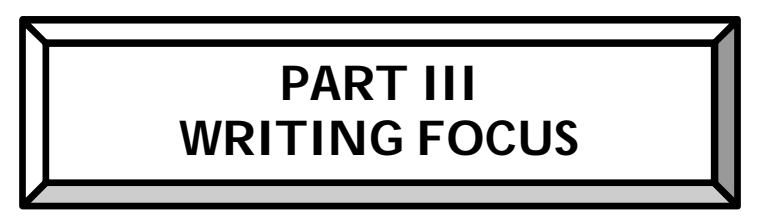

In this unit, you will write a process paragraph about something you know how to do that might be helpful to someone else. 


\section{Exercise 1}

\section{Brainstorming ideas}

A. Think of some tasks and activities that you do often. Write them in the chart below. Then select one or two that are processes that require steps. Finally, put a check next to those activities that might be good topics for a process paragraph.

\begin{tabular}{|c|c|}
\hline Time & Tasks and activities \\
\hline Morning & \\
\hline Afternoon & \\
\hline Evening & \\
\hline Weekend & \\
\hline
\end{tabular}

B. Describe one of the tasks or activities in the chart to a partner.

\section{Exercise 2 Brainstorming vocabulary}

C. Circle the words that you might like to use in your writing. Then add two or three words to each list.

\begin{tabular}{|l|l|}
\hline Measure & a foot, a pound, a tablespoon, \\
\hline Use & a knife, a hammer, a pencil, a pair of scissors, \\
\hline Fill & a container, a bucket, a bottle, a bowl, \\
\hline Insert & a screw, a wire, a hook, a tube, \\
\hline
\end{tabular}

Journal on English as a Foreign Language, 7(1), 97-118

Copyright (C) 2017 by JEFL, p-ISSN 2088-1657; e-ISSN 2502-6615 


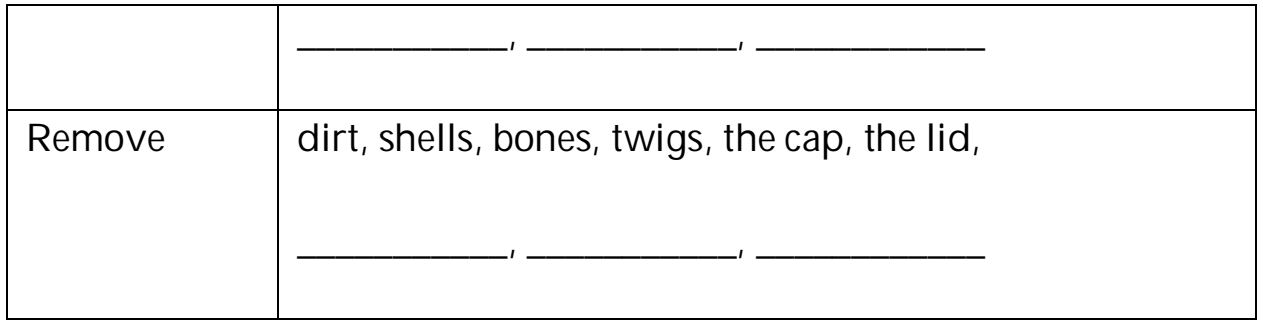

D. On a separate piece of paper, use vocabulary from the chart to write five sentences about your process.

\section{Exercise 3 Writing an outline}

Review your brainstorming ideas and your free writing exercise. Then use the chart below to write an outline for your process paragraph.

\section{Exercise 4}

\section{Writing a first draft}

Review your outline. Then write your first draft of a process paragraph about something you know how to do that might be helpful to someone else.

\section{Exercise 5 Editing and revising the first draft}

After you write your first draft, exchange it with a partner. Answer the questions on the checklist. You may also write comments or questions on your partner's draft. Read your partner's comments on it, and revise it as necessary. Then write a final draft. 